\title{
Refractory Wegener's granulomatosis presenting with alveolar haemorrhage, treated with rituximab
}

\author{
Joana Caetano, ${ }^{1}$ Marisa Fernandes das Neves, ${ }^{1,2}$ Susana Oliveira, ${ }^{1}$ \\ José Delgado Alves ${ }^{1,2}$
}

'Department of Medicine 4, Fernando Fonseca Hospital, Amadora, Portugal ${ }^{2}$ CEDOC - Center for Chronic Diseases of NOVA Medical School, Lisbon, Portugal

\section{Correspondence to}

Professor José Delgado Alves, jose.alves@fcm.unl.pt

Accepted 28 November 2014

\section{DESCRIPTION}

A previously healthy 57-year-old man presented with epistaxis, crusted nasal ulcers and weight loss. CT scan of the sinuses revealed an inflammatory swelling of the ethmoid and maxillary sinuses (figure 1) and CT scan of the lungs showed two pulmonary nodular lesions in both upper lobes. Laboratory investigation showed an elevated erythrocyte sedimentation rate $(97 \mathrm{~mm} / \mathrm{h})$ and a positive anti-PR3-antineutrophil cytoplasmic antibody.

The diagnosis of Wegener's granulomatosis (WG) was made and the patient was started on immunosuppression with cyclophosphamide and glucocorticoids followed by maintenance therapy with azathioprine, with subsequent disease remission.

After 2 years, the disease relapsed with haemoptysis and external popliteal sciatic mononeuropathy. A thoracic CT scan revealed multiple pulmonary nodular lesions and ground-glass infiltrate of the right lower lobe, compatible with alveolar haemorrhage (figure 2). The patient started treatment with rituximab with completely resolution of the symptoms and pulmonary lesions. He remained asymptomatic at 2-year follow-up.

WG is a primary systemic vasculitis, with predilection for the respiratory tract and kidney involvement. Although pulmonary findings are common, diffuse alveolar haemorrhage is a rare and lifethreatening manifestation of WG. It is associated with six times greater mortality than vasculitis without pulmonary haemorrhage. ${ }^{1}$

Cyclophosphamide is still the standard induction therapy for patients with WG. Nevertheless, relapse

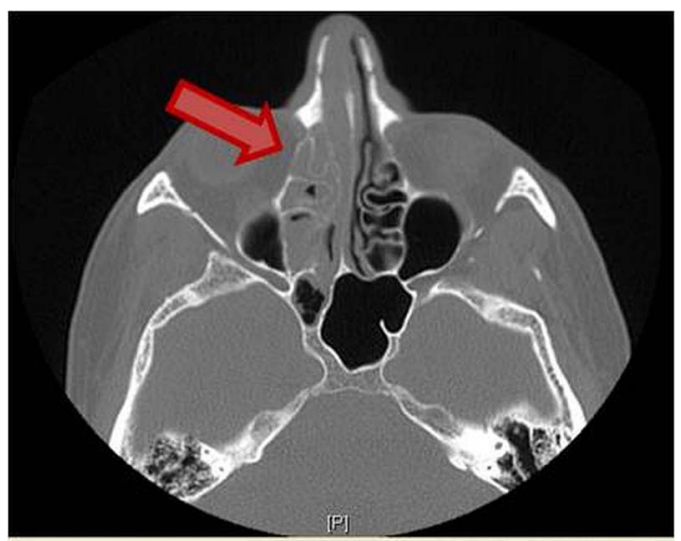

Figure 1 CT scan of the sinuses showing an inflammatory swelling of the ethmoid and maxillary sinuses (arrow).

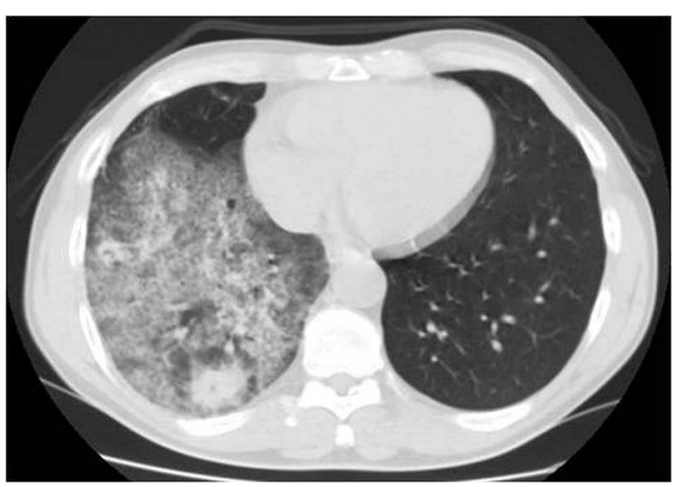

Figure 2 Thoracic CT scan showing pulmonary nodular lesions and alveolar haemorrhage in the right lower lobe.

is common in up to $50 \%$ of patients and rituximab has been proving to be an effective remission inducing agent in severe refractory WG. ${ }^{12}$

\section{Learning points}

Despite the poor outcome of patients with alveolar haemorrhage, it can have a benign course with prompt immunosuppression.

- Rituximab is an effective immunosuppressive therapy for the induction and maintenance of remission in refractory Wegener's granulomatosis.

- As most patients with antineutrophil cytoplasmic antibody associated-vasculitis relapse, a close monitoring of the patients is crucial for an early diagnosis and therapeutics.

Contributors $\mathrm{JC}$ and MFN participated in drafting of the manuscript. JDA and SO revised it critically for important intellectual content. All the authors contributed to conception of the work and acquisition of data.

Competing interests None.

Patient consent Obtained.

Provenance and peer review Not commissioned; externally pee reviewed.

\section{REFERENCES}

1 Thickett DR, Richter AG, Nathani N. Pulmonary manifestations of anti-neutrophil cytoplasmic antibody (ANCA)-positive vasculitis. Rheumatology 2006;45:261-8.

2 Specks U, Merkel PA, Seo P, et al. Efficacy of remission-induction regimens for ANCA associated-vasculitis. N Engl J Med 2013;369: 417-27 
Copyright 2014 BMJ Publishing Group. All rights reserved. For permission to reuse any of this content visit http://group.bmj.com/group/rights-licensing/permissions.

BMJ Case Report Fellows may re-use this article for personal use and teaching without any further permission.

Become a Fellow of BMJ Case Reports today and you can:

- Submit as many cases as you like

- Enjoy fast sympathetic peer review and rapid publication of accepted articles

- Access all the published articles

- Re-use any of the published material for personal use and teaching without further permission

For information on Institutional Fellowships contact consortiasales@bmjgroup.com

Visit casereports.bmj.com for more articles like this and to become a Fellow 